Research Article

\title{
Pandemic Dynamics, the three Waves of COVID- 19 and the Way Ahead
}

\author{
Badrinarayan Mishra', Bidushi Mishra', Gitisha Mishra ${ }^{3}$, Nidhi D Sinha ${ }^{4}$ \\ ${ }^{1}$ Professor, Community Medicine, Ruxmaniben Deepchand Gardi Medical College, Ujjain, Madhya Pradesh, India. \\ ${ }^{2} 2^{\text {nd }}$ Year BDS, Peoples College of Dental Sciences and Research Centre, Bhopal, Madhya Pradesh, India. \\ ${ }^{3} 12^{\text {th }}$ Std., Carmel Convent Senior Secondary School, Ujjain, Madhya Pradesh, India. \\ ${ }^{4}$ Associate Professor, Department of Dentistry, Ruxmaniben Deepchand Gardi Medical College, Ujjain, Madhya Pradesh, India. \\ DOI: https://doi.org/10.24321/2394.6539.202102
}

\section{I $\quad \mathbf{N} \quad \mathbf{F} \quad \mathbf{O}$}

\section{Corresponding Author:}

Badrinarayan Mishra, Community Medicine, Ruxmaniben Deepchand Gardi Medical College, Ujjain, Madhya Pradesh, India.

E-mail Id:

badrinmishra@gmail.com

Orcid Id:

https://orcid.org/0000-0001-6956-0469

How to cite this article:

Mishra B, Mishra B, Mishra G, Sinha ND. Pandemic Dynamics, the three Waves of COVID-19 and the Way Ahead. J Adv Res Med Sci Tech 2021; 8(1): 13-18.

Date of Submission: 2021-01-05

Date of Acceptance: 2021-02-01

\section{$\begin{array}{llllllll}\mathbf{A} & \mathbf{B} & \mathbf{S} & \mathbf{T} & \mathbf{R} & \mathbf{A} & \mathbf{C} & \mathbf{T}\end{array}$}

Spread of a new pandemic in waves is a natural phenomenon. It has happened in past and also unfolding in present COVID-19 scenarios. Many players determine the outcome of the diseases during these waves of activities. This article discusses the past pandemics, lessons learnt from them and the 3 waves that have been recorded to date for SARS-CoV-2 (the novel coronavirus) and drawing parallel wherever feasible along with an element on its future course.

Keywords: Pandemic Dynamics, SARS-CoV-2 Waves, Way Ahead

\section{Introduction}

As per World meter, COVID-19 CORONAVIRUS PANDEMICLast updated: December 12, 2020, 04:00 GM and WHO (World Health Organization) Coronavirus Disease (COVID-19) Dashboard, Globally, there are over 71,43 million confirmed cases of COVID-19, including 1,6 million (3\%) deaths. ${ }^{1}$ The virus has so far affected 218 countries and territories along with 2 international conveyances. ${ }^{2,3}$

This has not happened overnight. Since its official confirmation by WHO on Dec 31 - 2019, the novel COVID-19 has stretched to this unfortunate record-breaking achievement in just little over 11 months and no one is sure how many more human lives and sufferings will be in its ambit till we tame this dragon.

Top five pandemics in human history: A look back into the history of medicine unravels the black days of human suffering due to devastating epidemics that swept the globe one after the other at different points in time. If we try to enlist them in terms of human suffering (number affected) the list will look something like this ${ }^{3,4}$ (Table 1). 
Table I.The top 5 worst pandemics in terms of affected population of the world till date (I2 Dec 2020)

\begin{tabular}{|c|c|c|c|c|c|c|c|}
\hline Rank & Pandemic & Year of Occurrence & $\begin{array}{l}\text { Lives } \\
\text { Lost in } \\
\text { Million }\end{array}$ & $\begin{array}{l}\text { Mortality } \\
\text { Rate }\end{array}$ & $\begin{array}{c}\text { Affected } \\
\text { Population } \\
\text { in Million }\end{array}$ & Rout of Spread & Containment \\
\hline 1. & Smallpox & $1877-1977$ & 500 & $35 \%$ & NA & Direct Contact & Vaccination \\
\hline \multirow[b]{2}{*}{2.} & (Plague) & & & & & & \\
\hline & $\begin{array}{l}\text { Antonine Plague } \\
\text { Justinian Plague } \\
\text { The Black Death }\end{array}$ & $\begin{array}{c}165 \text { AD (wave 1) } \\
541 \text { AD (Wave 2) } \\
1346-1353 \text { (wave 3) }\end{array}$ & $\begin{array}{c}5 \\
25 \\
200\end{array}$ & $\begin{array}{l}10 \%-90 \% \\
\text { (treated vs } \\
\text { untreated) }\end{array}$ & NA & $\begin{array}{l}\text { Droplets, Direct } \\
\text { Contacts and } \\
\text { Rat Flea Bites }\end{array}$ & $\begin{array}{l}\text { Quarantine, } \\
\text { Antibiotics }\end{array}$ \\
\hline \multirow{5}{*}{3.} & Flu Pandemic & & & & & & \\
\hline & Asian Flu & 1889 ( $1^{\text {st }}$ Wave $)$ & 1 & $20 \%$ & NA & & \\
\hline & & $\begin{array}{c}\text { 1956-1958 ( } 2^{\text {nd }} \\
\text { Wave) }\end{array}$ & 1 & \multirow[t]{2}{*}{$\begin{array}{l}0.1 \% \\
-0.5 \%\end{array}$} & \multirow[t]{2}{*}{ NA } & \multirow[t]{2}{*}{ Droplet } & \multirow{2}{*}{$\begin{array}{c}\text { Mask, Luck } \\
\text { down, } \\
\text { Quarantine, } \\
\text { Vaccine }\end{array}$} \\
\hline & & 1968 (3rd Wave) & 1 & & & & \\
\hline & Spanish Flu & 1918 - 1919 & 50 & $2.5 \%$ & $\begin{array}{c}500 \text { Or } \\
1 / 3 r d \text { Of } \\
\text { Population } \\
\text { then }\end{array}$ & & $\begin{array}{l}\text { Mask, Luck } \\
\text { down, } \\
\text { Quarantine, }\end{array}$ \\
\hline 4. & HIV/ AIDS & 1981 - Till Date & 40 & & 81.06 & Body Fluids & $\begin{array}{c}\text { Anti- } \\
\text { Retroviral } \\
\text { Drugs }\end{array}$ \\
\hline 5. & COVID-19 & $\begin{array}{c}\text { Dec. } 2019 \text { - Dec. } \\
2020\end{array}$ & $1.69 *$ & $3 \%$ & $77,70 *$ & $\begin{array}{l}\text { Droplet, } \\
\text { fomites, Air } \\
\text { born }\end{array}$ & $\begin{array}{c}\text { Mask, Social } \\
\text { Distancing, } \\
\text { Hand } \\
\text { Hygiene, } \\
\text { Drugs (?) }\end{array}$ \\
\hline
\end{tabular}

*Ref. number 1. NA- data not available.

As evident from the above table (number 1 ); SARS-CoV-2 or COVID-19 as it is popularly called has very efficiently marked its presence felt and superseded many known pandemics of the past and presently placed at $5^{\text {th }}$ place in just under a year. If unabated, it may profess serious threats to its nearest contender HIV/ AIDS and preferably shall overtake it by Jan 2021 (at its current trend), which has laboured close to 4 decades to establish its claim.

As COVID-19 is demonstrating the usual course of pandemic progression which happens in waves, it may leave us biting our nails in desperation and disgust. Compelling us to introspect on diverge fronts and asking ourselves a million questions about our scientific endeavour.

Pandemics waves: Smallpox the number one in the list that spanned from 735 AD till its eradication on 1977 had experienced 23 waves. The 735 AD Japanese smallpox killed 2,000,000 people in just 2 years, the next wave or resurgence was Mexican smallpox that killed 5,000,000 in just in one-year (1519-1520) and the most devastating wave that resulted in $500,000,000$ deaths continued for 100 years (1877-1977)..$^{5-8}$

Similarly, the second pandemic in the list caused by the bubonic and pneumonic plague with a huge mortality range of $10 \%$ to $90 \%$ shattered the populace. The available records state it started as Antonine Plague as early as 165 AD. But the most noted one in terms of waves or resurgences was the great plague of London (1348-1665) that demonstrated over 40 waves and lead to 3,000,000 lives lost. ${ }^{9-12}$

Spanish flu the close cousin to COVID-19 killed about $50,000,000$ people in just one year (1918-1919) and had 3 distinct waves during that time. The second wave also called the 'fall wave' that happened during winter months was the most lethal (Figure number 1 ). ${ }^{13}$ Since then, we have experienced flu outbreaks on 1957-1958, 1968-1969, 1977 1978 and 2009-2010 those were caused by descendants of H1N1 (Spanish Flu) but none of them was as bad as 1918. ${ }^{14-19}$ Lessons learnt from flu epidemics: Spanish flu the 'mother 


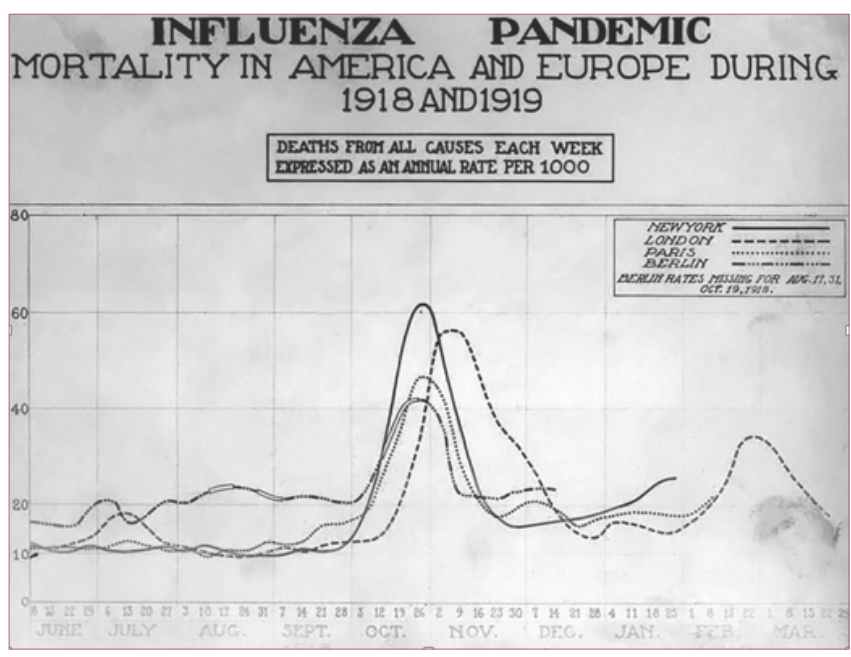

Figure I.The 3 waves of Spanish flu

of all pandemic' that occurred during 1018-1019 killed more people than those killed by both the world wars combined (I and II) and affected over $1 / 3^{\text {rd }}$ population of the time. ${ }^{19}$ It experienced 3 waves across all continents in a dramatically similar fashion (Figure 1). The second wave that took all by surprise recorded 5 times more mortality than the first one (Figure 2) and demonstrated a ' $W$ ' pattern where more of young unexposed adults aged 20-40 years were infected instead of the conventional ' $U$ ' pattern that represents the involvement of children $<5 y$ rs and adults $>75 \mathrm{yrs}^{20}{ }^{20}$ The high mortality and $\mathrm{W}$ pattern is attributed to new recruitments of non-immune young individuals to the army, occurrence of post-infection 'cytokine storm' (an excessive inflammatory response) among them leading to severe complications and death, rapid mass movement of soldiers in overcrowded and unhygienic conditions, stationing of soldiers in inhabitable overcrowded trenches, diversion of health resource to attain war victims and nearcomplete disregards to preventive public health measures during war time. ${ }^{21}$

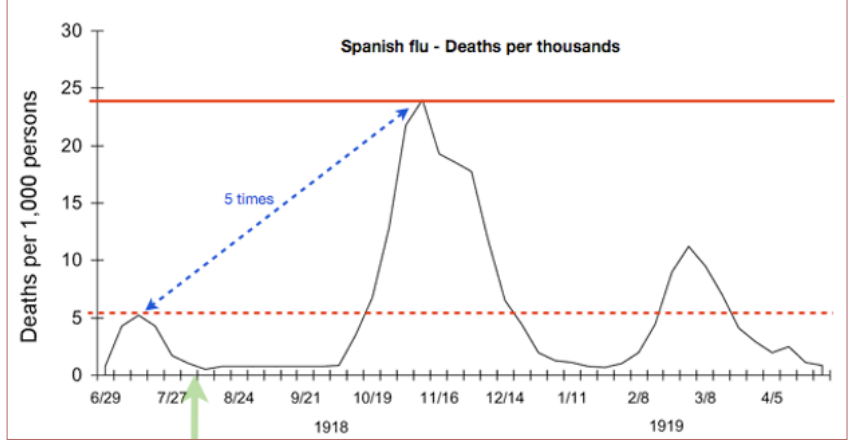

Figure 2.The 3 waves of Spanish flu measured in terms of weeks highlighting the devasting fall wave ( $2^{\text {nd }}$ wave)

The subsidence of the flu pandemic occurred not because of potent therapy, or vaccines none of them were available then and even thereafter(for a long time); but of implementation of stringent non-pharmacological public health measures like social distancing, use of face masks, the shutdown of schools, theatres and market places (though it came late, mostly post-war), end of the world war 1 leading to declining in the mass movement of troops, the role of 'theory of natural selection' where most seriously ill patients died after a brief illness (within 24 hours of the appearance of the first signs of infection) thus limiting the spread of the mutant virulent strain and giving opportunity for the development of less virulent mutants, construction of makeshift morgues to amass dead bodies and development of herd immunity in living population. ${ }^{22,23}$

For time to come, viral pandemics will remain as a constant challenge. It is prudent that we learn from each passing ones and equipped our self well to handle new ones like the present COVID-19.

\section{Disease Waves, COVID- I 9 Present Trend and Dynamic}

Disease Waves: Though there are no definitive criteria that define a disease wave, a practical assumption to satiate most is a rhythmic or definite pattern of disease occurrence that alternates between spikes and plateaus (Figure 1 and 2). This natural pattern of peaks followed by declines has been noticed with many infectious diseases with epidemic or pandemic potentials. There are reports of the wide variability in the frequency and severity of disease waves that depends on factors like its infectivity, mortality, novelty, mutation potential, the population affected, immunologic responses and seasonality. This pattern continues till we find a lasting solution in form of vaccines and/ or specific therapy. Till then many non-pharmacological measures can keep them in check and buy time for developing viable resources.

\section{COVID- 19 and its Propagation Dynamics}

SARS-CoV-2 belongs to the third group of the coronavirus that has put the world in turmoil. The preceding ones being Severe Acute Respiratory Syndrome (SARS) and Middle East Respiratory Syndrome (MERS) of 2003 and 2012 respectively. ${ }^{24}$ All of them demonstrates some common clinical characters that span across mild upper respiratory illness to Acute Respiratory Distress Syndrome (ARDS) necessitating intensive care in addition to their own specific manifestations. COVID-19 tops the list in terms of diverging manifestations, swiftness in the spread, multiorgan involvements and 'long hauliers' numbers. The factors rendering favourable support to COVID-19 in terms of proficiency of spread are its' high R nought ( 0 ) and lower crude mortality rate. These two factors in addition to a virgin population while helped its spread but at the same time not permitted it to mutate significantly. Those mild 
mutations of which 'six' are in the present-day record $(L, S$, V, G, GR, GH), are serving as a boon to vaccine and therapy development. ${ }^{25-28}$

COVID waves: The latest mutant G carrying D614G mutation in its spike protein is dominating the world at present while the initial $L$ form that originated from China and its subsequent $\mathrm{S}$ mutant is nearly extinct. The $\mathrm{G}$ mutants like GR and GH have recorded high infectivity in both Europe and the Americas. ${ }^{26-28}$ As per the WHO Weekly epidemiological update $8^{\text {th }}$ December 2020, the different WHO regions are in different phases of pandemic progression. The global pandemic mortality shows 3 distinct waves of which the $3^{\text {rd }}$ one is the worst. Americas are experiencing its $3^{\text {rd }}$ wave both in terms of cases and deaths, the other regions besides South East Asia are in their $2^{\text {nd }}$ wave. Though South East Asian countries are still experiencing its first wave but reports of $2^{\text {nd }}$ and even $3^{\text {rd }}$ waves in select high dense cities and provinces are increasingly reported. ${ }^{29}$ The world scenario as on 6th December 2020 is presented in Figure 3.

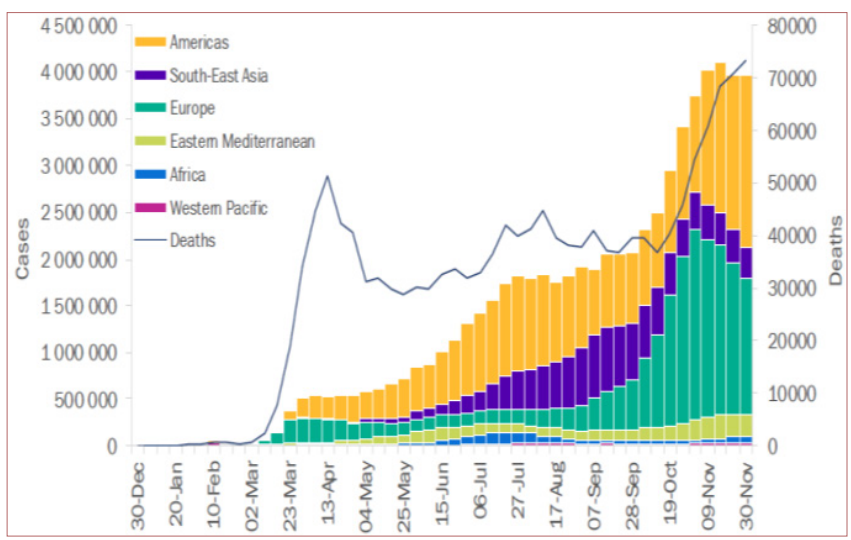

Figure 3.COVID- I 9 cases reported weekly by WHO Region, and global deaths, as of 6 December 2020

This differing scenario for different WHO regions has many contributing factors which are mainly geopolitical and social-cultural. Europe and the Americas had a 'go loose' approach for the infection at the early stage which allowed the virus to mutate and spread within and beyond their geographical limits. But the fortunate part is sooner or later most countries went into sever lockdown enforcing restriction on population movement. This did a world of good in terms of restriction of spread and scope to mutate for the virus and provided the much-needed time for the health sector to organize and stockpile resources. The subsequent policy of increased testing, contact tracking, nonpharmacological isolation measures like universal mask use, social distancing, weekend curfew, restricted sociocultural activities with limited participants has somewhat managed to keep things getting out of control.

But pandemic and long-term restriction fatigue is being increasingly reported and the result is eminent in new spikes wherever it happened. This recurrence presenting as new waves and the absence of specific medications and a potent vaccine is a major point of concern. While the scientists across the globe have gone all out in finding a lasting solution especially in developing efficient vaccines and inventing lethal medications it's time for all to be patient and discharge their social responsibility till, we succeed in this direction. The virus in the present state has demonstrated mild nonsignificant mutation and is sensitive to most vaccines those are in the trial (currently more than 50 COVID-19 vaccine candidates in trials) and some (Pfizer/ BioNTech vaccine) have been rolled out recently for public use. ${ }^{30}$

The Way Ahead: Considering all the above factors scientist have developed different predicting models for the pandemic. In one such popular projections designed by statista.com the projected deaths for two pre-specified time, one covering Oct. 1 to Dec. 31, 2020, and the later from Dec. 1, 2020, to Mar. 31, 2021, are presented in figure number 4 ' $A$ ' and ' $B$ '. ${ }^{31}$ The factors considered are.

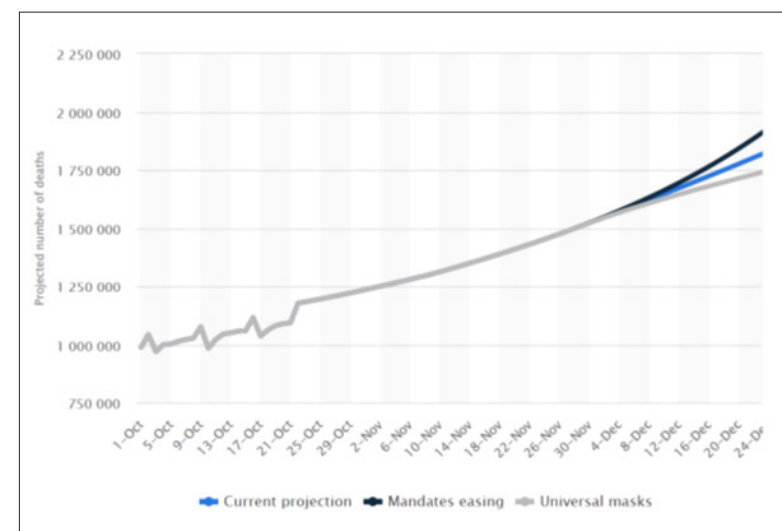

A

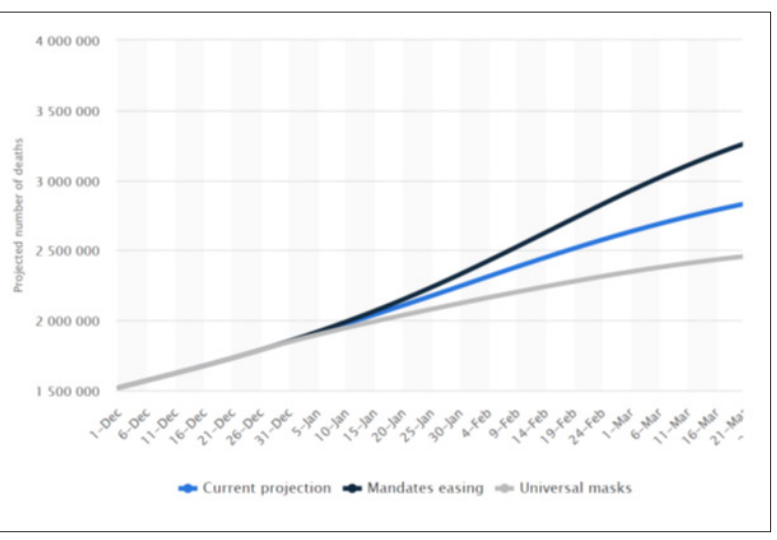

B

Figure 4.World-wide COVID-I 9 I9-projected-deaths-by-scenario, A (Oct. I to Dec. 3 I, 2020) and B, (Dec. I, 2020 to Mar. 3I, 202I) 
- Mandates Easing: Which means continued easing of social distancing mandates, and mandates are not re-imposed thereafter.

- Current Projection: Mandates are re-imposed for six weeks whenever daily deaths reach eight per million.

- Universal Masks: Where 95\% of the population use mask in every location, with mandates re-imposed for six weeks if daily deaths reach eight per million.

The benefits of the most rational and sensible approach as under universal masking category is evident in both the graphs. Part ' $\mathrm{B}$ ' predicts the COVID-19 deaths to swell to 2.5 to 3.4 million for the best to the worst-case scenario (universal masking - mandates easing) from the present figure of 1.6 million.

Another prediction needing a mention is designed by The Kansas Business Group on Health (KBGH) way back in $17^{\text {th }}$ April 2020. ${ }^{32}$ They and a host of other prediction models used disease parameters which studied the pandemic dynamics based on COVID-19 transmissibility; measured by RO, R treat, R cure indices, mean or median incubation period, serial interval, confirmed Case Fatality Rate (cCFR) and Control Measures studied in terms of travel Restrictions, non-pharmaceutical Interventions, quarantine and airport Screening etc. ${ }^{33,34}$ The Kansas Business Group on Health predicted three scenarios as presented below in Figure 5.

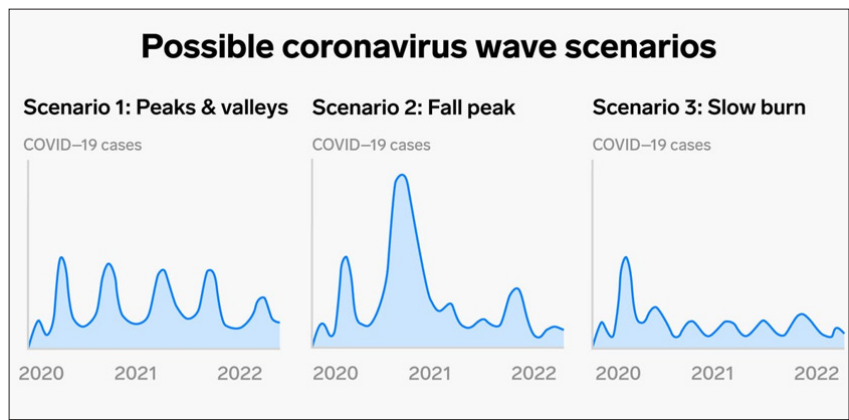

Figure 5.Possible COVID Waves

As the situation has progressed, scenario 2 seems a more appropriate predictor especially with the availability of vaccines around the corner.

\section{A Ward on Current Vaccine Scenario}

The Pfizer/BioNtech vaccine is already commissioned in the United Kingdoms, Canada and US. It has demonstrated a 95\% effectiveness ( 2 weeks after the $2^{\text {nd }}$ dose) in trial stages, and given in two doses 3 weeks apart. But the problem with the vaccine is its cold-chain which asks for $-70^{\circ} \mathrm{C}$ for transportation and storage.

Moderna vaccine which uses the same approach as the Pfizer vaccine has a protection level of $94.5 \%$. It is administered 4 weeks apart and its big plus point is a more feasible cold chain requires $-20^{\circ} \mathrm{C} .^{35}$

\section{Conclusion}

COVID-19 is surrounded by numerous uncertainties. We have made undeniable progress in the field of novel innovations (use of Far UVC), vaccine development but there is a long way to go. The virus is not an easy pushover. ${ }^{36}$ It has begun to show new properties and multiple mutations. Certain problems are still unanswered; like the issue of reinfection, routes of entry and its further progress, uncertainties about new manifestations and long-term persistence (long COVID-19) to name a few. ${ }^{37}$ The time is not ripe to lower our guards till the battle is owned.

\section{Conflicts of Interest: None}

\section{References}

1. COVID-19 CORONAVIRUS PANDEMIC world meter; Last updated: Last updated: December 20, 2020, 10:09 GMT. www.worldometers.info (/coronavirus/)

2. WHO Health Emergency Dashboard WHO (COVID-19) Homepage.

3. Novel Coronavirus (2019-nCoV) situation reports World Health Organization (WHO).

4. The Deadliest Pandemics in History; Julia Tortorice; Nursing CE; OCTOBER 13, 2020. Copyright (C) CEUFast. com, 2015-2020. www.history.com/news/pandemicsend-plague-cholera-black-death-smallpox.

5. Nishiyama Y, Matsukuma S, Matsumura T, Kanatani Y, Saito T. Preparedness for a smallpox pandemic in Japan: public health perspectives. Disaster Med Public Health Prep 2015; 9(2): 220-3. DOI: 10.1017/dmp.2014.157. PMID: 26060873.

6. Sanfilippo-Borrás J. Algunas enfermedades y epidemias en torno a la Revolución Mexicana [Epidemics and disease during the Revolution Period in Mexico]. Rev Med Inst Mex Seguro Soc 2010; 48(2): 163-6. Spanish. PMID: 20929620.

7. Strassburg MA. The global eradication of smallpox. Am J Infect Control 1982; 10(2): 53-59. DOI: 10.1016/01966553(82)90003-7. PMID: 7044193

8. ABBAS M. BEHBEHANI. The Smallpox Story: Life and Death of an Old Disease. Microbiological Reviews, American Society for Microbiology Dec 1983; 47(4): 455-509.

9. Haas C. La peste antonine [The Antonine plague]. Bull Acad Natl Med 2006; 190(4-5): 1093-8. French. PMID: 17195627.

10. Sáez A. La peste Antonina: una peste global en el siglo II d.C [The Antonine plague: A global pestilence in the II century d.C]. Rev Chilena Infectol 2016; 33(2): 218-21.

11. Collingwood F. The Great Plague Of London, 1665. Nurs Times 196530; 61: 591.

12. Sloan AW. Medical and social aspects of the great plague of London in 1665. S Afr Med J 1973; 47(7): 270-6. 
13. Promenade E. Living With 'Enza: The Spanish Flu Pandemic, 1918-1919. HEALTH. YOUR \#1 Source for Edwardian History! February 12, 2012.

14. Nickol ME, Kindrachuk J. A year of terror and a century of reflection: perspectives on the great influenza pandemic of 1918-1919. BMC Infect Dis 2019; 19(1): 117. DOI: $10.1186 / \mathrm{s} 12879-019-3750-8$.

15. Aubenberger JK, Morens DM. 1918 Influenza: the mother of all pandemics. Emerg Infect Dis 2006; 12(1): 15-22.

16. Martini M, Gazzaniga V, Bragazzi NL, Barberis I. The Spanish Influenza Pandemic: a lesson from history 100 years after 1918. J Prev Med Hyg 2019; 60(1): E64-E67.

17. He D, Dushoff J, Day T et al. Mechanistic modelling of the three waves of the 1918 influenza pandemic. Theor Ecol 4 2011; 283-288.

18. Finnegan G. 100 Years After 'Spanish Flu': Is The World Ready for the Next Pandemic? October 24 ${ }^{\text {th }}, 2018$, Vaccines Europe.

19. Taubenberger JK, Morens DM. 1918 influenza: the mother of all pandemics. Emerg Infect Dis 2006; 12(1): 15-22.

20. Martini M, Gazzaniga V, Bragazzi NL, Barberis I. The Spanish Influenza Pandemic: a lesson from history 100 years after 1918. J Prev Med Hyg 2019; 60(1): E64-E67.

21. Morens DM, Taubenberger JK, Harvey HA, Memoli MJ. The 1918 influenza pandemic: lessons for 2009 and the future. Crit Care Med 2010; 38(4 Suppl): e10-20.

22. Taubenberger JK. The origin and virulence of the 1918 "Spanish" influenza virus. Proc Am Philos Soc 2006; 150(1): 86-112.

23. Nickol ME, Kindrachuk J. A year of terror and a century of reflection: perspectives on the great influenza pandemic of 1918-1919. BMC Infect Dis 2019; 19: 117.

24. Chen N, Zhou M, Dong $X$ et al. Epidemiological and clinical characteristics of 99 cases of 2019 novel coronavirus pneumonia in Wuhan, China: a descriptive study. Lancet 2020.

25. Petrosillo N, Viceconte G, Ergonul O, Ippolito G, Petersen E. COVID-19, SARS and MERS: are they closely related? Clin Microbiol Infect 2020; 26(6): 729-734.

26. Kaur N, Singh R, Dar Z, Bijarnia RK, Dhingra N, Kaur T. Genetic comparison among various coronavirus strains for the identification of potential vaccine targets of SARS-CoV2. Infect Genet Evol 2020; 104490.

27. Daniele Mercatelli, Federico M. Giorgi. Geographic and Genomic Distribution of SARS-CoV-2Mutations. Frontiers in Microbiology 2020; 11. DOI: 10.3389/ fmicb.2020.01800

28. Università di Bologna. The six strains of SARS-CoV-2. ScienceDaily. ScienceDaily, 3 August 2020.<www. sciencedaily.com/relases/2020/08/200803105246.htm

29. Weekly epidemiological update-8 December 2020.
Data, as received by WHO from national authorities, as of 10, am CET 6 December 2020.8 December 2020; | Emergency Situational Updates.

30. Mercatelli D, Giorgi FM. Geographic and Genomic Distribution of SARS-CoV-2 Mutations. Front Microbiol 2020; 11: 1800.

31. https://www.statista.com/statistics/1176553/covidprojected-deaths-by-scenario

32. Moore J. The Kansas Business Group on Health (KBGH). Social isolation doesn't cause recessions - pandemics do. Posted on 17 Apr 2020.

33. Goyal R. Measurement of Contagiousness/Infectiousness/ Transmissibility of Infectious Agent. J Adv Res Med Sci Tech 2020; 7(1): 1-3.

34. Minah Park, Cook AR, Lim JT et al. A Systematic Review of COVID-19 Epidemiology Based on Current Evidence. J Clin Med 2020; 967: 1-13.

35. James Gallagher. Covid vaccine: First 'milestone' vaccine offers $90 \%$ protection. BBC News. $8^{\text {th }}$ December 2020.

36. Mishra B, Sinha ND, Mishra MB, Mishra MG. Is 'FAR UVC' the Nearest Solution for Pandemic Containment? J Adv Res Med Sci Tech 2020; 7(3): 27-31.

37. Mishra B, Mohapatra SC. Nasal ACE 2 receptors' the gateway to COVID 19? J Community Health Manag 2020; 7(3): 68-69. 